
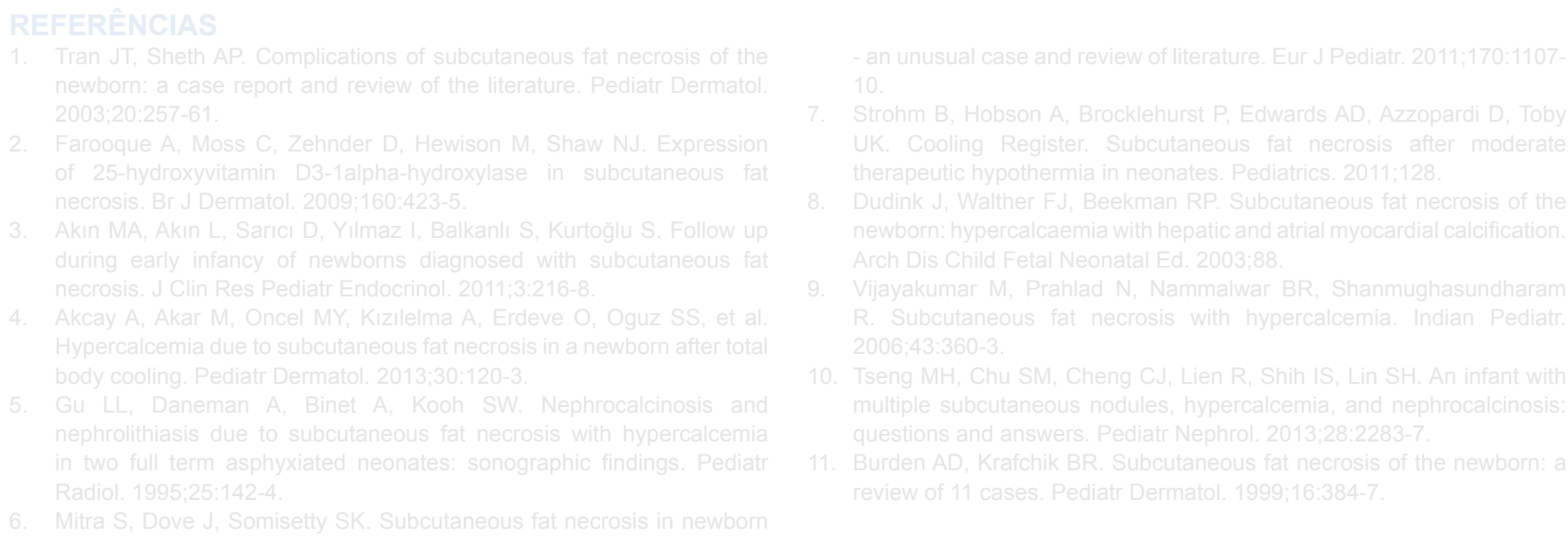

\title{
Secondary Rhinoplasty Using the Technique of Turkish Delight: a Case Report and a Brief Review of the Literature
}

\author{
Rinoplastia Secundária com a Técnica de Turkish Delight: Relato de Caso e \\ Breve Revisão Bibliográfica
}

\author{
Inês CORREIA-SÁ ${ }^{1,2}$, José AMARANTE ${ }^{1,2}$, Ricardo HORTA ${ }^{1}$, Tiago NETO ${ }^{1}$, Álvaro SILVA ${ }^{1}$, Marisa MARQUES ${ }^{1,2}$ \\ Acta Med Port 2015 Jan-Feb;28(1):122-126
}

\section{ABSTRACT}

Rhinoplasty is a demanding task, especially when augmentation of the nasal contour is required. Autologous cartilage grafts are challenging. Contour and alignment of the graft are difficult goals. It is presented a case of a successfully nasal dorsum augmentation in a secondary rhinoplasty with the Turkish Delight technique and a brief review of literature. A 33-years-old female, with history of complete unilateral cleft nasal deformity on the right, and severe nasal deformity, previously submitted to other procedures, was referred to our Center. As she presented a visible cartilage graft, it was decided to perform the Turkish Delight technique. The autograft was effective for increasing of the nasal dorsum, at four years post-operative. There was no evidence of extrusion. The patient is satisfied with the result. The technique is effective in the reconstruction of complex dimorphism of the nasal dorsum, particularly in secondary rhinoplasty. Keywords: Cartilage/transplantation; Nose Deformities, Acquired; Rhinoplasty.

\section{RESUMO}

A rinoplastia é um procedimento cirúrgico exigente, especialmente quando requer aumento do contorno. Os enxertos de cartilagem, que visam melhorar o contorno e o alinhamento do dorso nasal são metas difíceis de alcançar. Apresenta-se um caso de uma rinoplastia secundária para aumento do dorso utilizando a técnica de Turkish delight e uma breve revisão de literatura. Uma mulher de 33 anos, com antecedentes de fenda palatina unilateral completa nasal à direita, e deformidade nasal grave, previamente submetida a outros procedimentos, foi encaminhado para o nosso Centro. Apresentava um enxerto de cartilagem visível, pelo que se optou pela técnica de Turkish delight. O enxerto mostrou-se eficaz no aumento do dorso aos quatro anos. Não ocorreu extrusão da cartilagem e a paciente está satisfeita com o resultado estético da cirurgia. A técnica é eficaz na reconstrução de dimorfismos do complexo do dorso nasal, particularmente em rinoplastias secundárias.

Palavras-chave: Cartilagem/transplantação ; Deformidades Adquiridas Nasais; Rinoplastia.

\section{INTRODUCTION}

Rhinoplasty is a demanding task in facial aesthetic surgery, especially when augmentation of the nasal dorsum is required. Although widely used, autologous cartilage grafts for the nose, present potential complications as later visibility, distortion, and absorption..$^{1-6}$ Contour and alignment of the graft are difficult goals, particularly in long term. Many techniques have been described to avoid these difficulties. Erol $^{7}$ described the Surgicel ${ }^{\circledR}$-wrapped diced cartilage graft technique (Turkish Delight), and reported successful use of this technique in both primary and secondary rhinoplasty, for augmentation and camouflage procedures in 2365 patients over a ten-year period, with only 11 cases of absorption. In the author experience, this technique would minimize the risk of postoperative malalignment or visibility, especially in thin skin patients, and it "presented as a pliable composite unit for rhinoplasty that could be shaped with the fingers.", eliminating the need of finding a perfectly straight dorsal graft, which can be difficult in secondary cases. ${ }^{7}$

1. Department of Plastic and Reconstructive Surgery. Hospital de S. João. Porto. Portugal.

2. Faculty of Medicine. University of Porto. Porto. Portugal.

Recebido: 17 de Maio de 2014 - Aceite: 23 de Dezembro de 2014 | Copyright $\odot$ Ordem dos Médicos 2015 
Although these impressive results in Erol's experience there are not, in our knowledge, any other report in the literature with patients treated with this technique. We present a case of a patient with severe nasal dorsum deformity, treated successfully with the Turkish delight technique, in a secondary rhinoplasty, and a brief review of the literature.

\section{CASE REPORT}

Thirty-three years-old female, with history of complete unilateral cleft nasal deformity on the right side, and severe nasal deformity (Fig.s 1, 2 and 3), presented at our Department. She had already been submitted, in another institution, to: 1) tip rhinoplasty; 2) Le Fort I, 3) rhinoplasty with rib graft, 4) auricular cartilage grafting for columella correction, and 5) turbinate reduction. She was dissatisfied with the cosmetic result. A facial CT revealed: sequels of previous surgeries performed (the Le Fortl surgery); insufficient volume of cartilage in nasal dorsum, and no septal deviation (Fig. 4). She presented a large cartilage defect, a visible cartilage graft in the nasal dorsum, and, as she had been submitted to several other surgery procedures, the nose skin was thin, which precluded another cartilage graft. After discussion the risks of the surgery with the patient, it was decided to perform a secondary rhinoplasty, with Surgice ${ }^{\circledR}$-wrapped diced cartilage graft technique (Turkish Delight) as previously described by Erol, ${ }^{7}$ without modification. Shortly, costal cartilage was harvested and cut in pieces of 0.5 to $1 \mathrm{~mm}$ using a no. 11 blade (Fig. 5a). One cubic centimeter of parental blood was obtained, and added to the cartilage to create a coherent mass. The cartilage was wrapped in a layer of Surgicel ${ }^{\circledR}$ (Surgicel $^{\circledR}$, Johnson\&Johnson, Skillman, N.J.), to obtain a cylindrical form, moistened with rifamycin and manually molded with the fingers into a suitable form (Fig. 5b). An adequately sized soft-tissue pocket larger than the graft was created and the cylinder was inserted under the dorsal nasal skin, into the nasal tip, under direct vision. A slight overcorrection
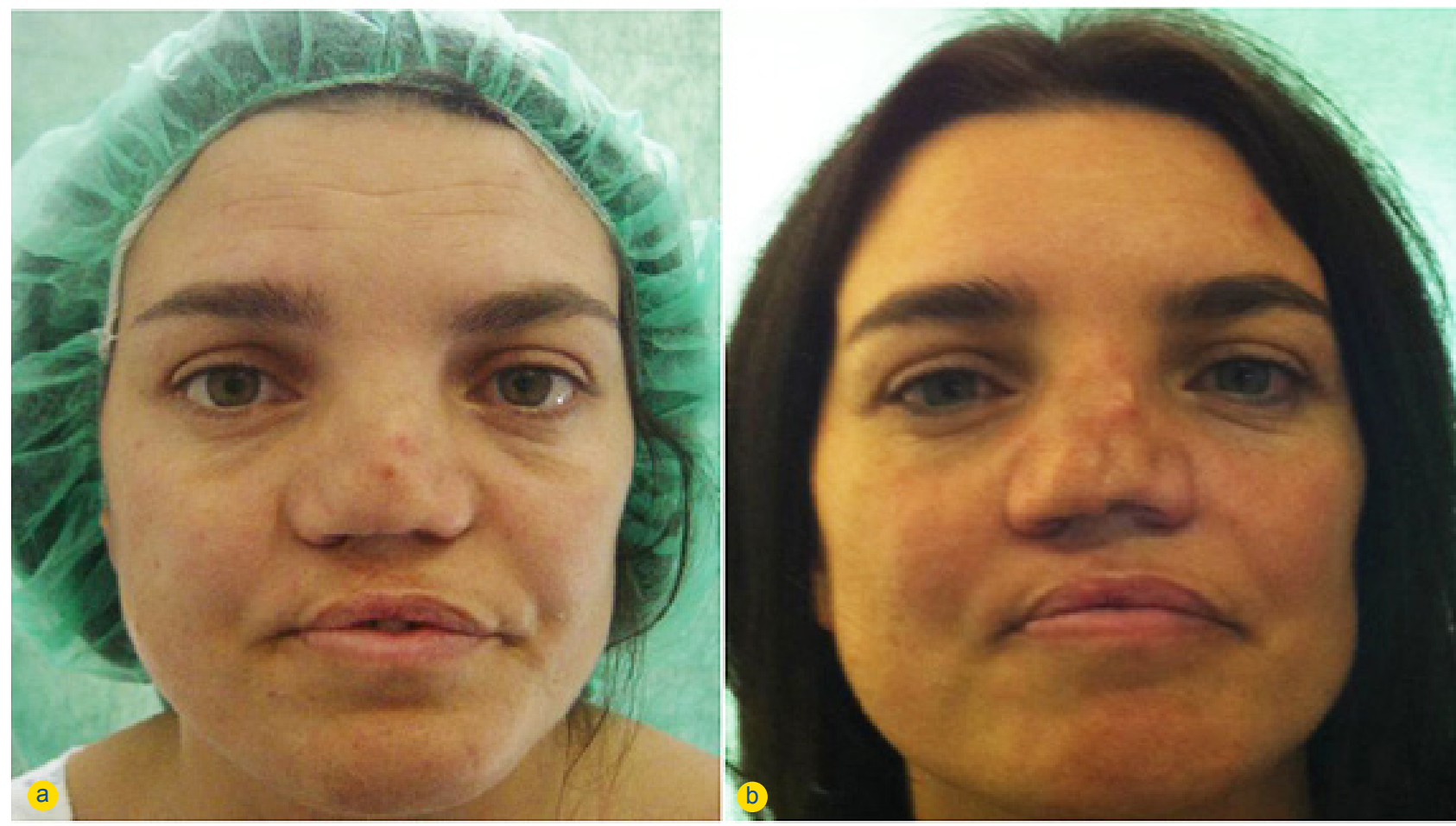

Figure 1 - Preoperative (a) and Postoperative (b) anterior view of the patient.
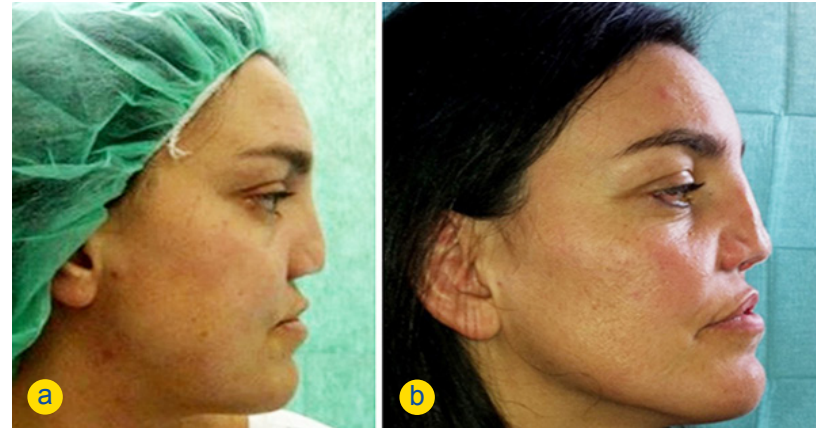

Figure 2 - Preoperative (a) and Postoperative (b) lateral view of the patient.

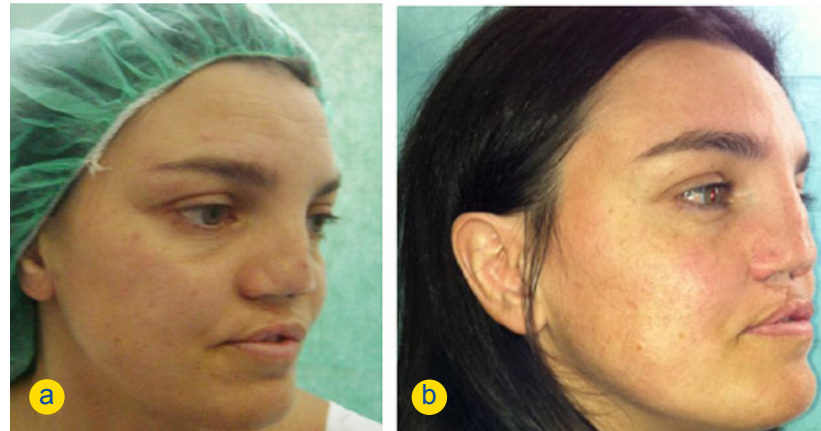

Figure 3 - Preoperative (a) and Postoperative (b) oblique view of the patient. 


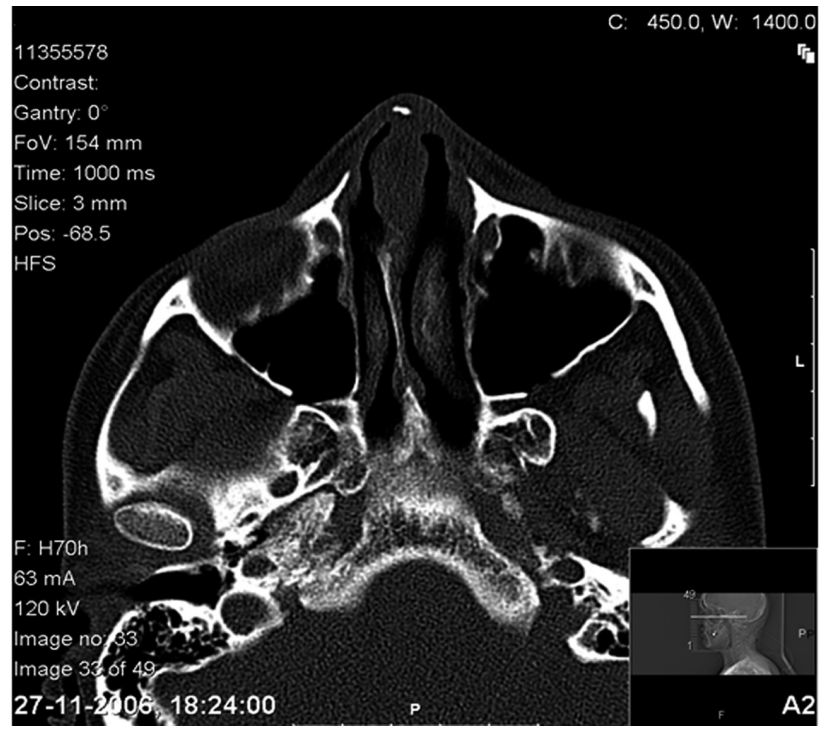

Figure 4 - Preoperative CT

was performed, as described. ${ }^{7}$ After insertion, intranasal incisions were closed, and the graft was molded from the outside by hand in order to eliminate ridges or other irregularities. A reconstruction of the columella strut-graft and a V-Y advancement flap of columella were performed.

External nasal taping with Steristrips, internal nasal packing with paraffin gauze and plaster cast were applied for seven days. After that period of time, the packing and cast were removed, and a slightly reshaping of the graft was performed, percutaneously. The patient was instructed to avoid manipulation of the nose for four weeks. A four years follow-up was performed. No acute or late complications were observed. The autograft was effective for increasing of the nasal dorsum, at four years (Fig.s 1, 2 and 3). There was no evidence of extrusion of the graft cartilage. The patient is satisfied with the aesthetic result of the procedure.

\section{DISCUSSION}

In 2000, $\mathrm{Erol}^{7}$ presented an outstanding work, describing a new technique for nasal augmentation with the use of Surgicel ${ }^{\circledR}$ wrapped diced cartilage. He described the use of this technique on 2365 patients over a ten-year period: 165 patients with traumatic nasal deformity, 350 patients with post rhinoplasty deformity, and 1850 patients during primary rhinoplasty. Erol ${ }^{7}$ reported a low rate of complications: early unusual postoperative swelling in six patients, persistent overcorrection owing to fibrosis in 16 patients, and excessive reabsorption beyond the expected amount in 11 patients. ${ }^{7}$ This presented particularly valuable technique for secondary rhinoplasty, avoiding visible or palpable contour irregularities in the areas of placement, a particular concern for patients with a thin, contracted skin envelope. ${ }^{8}$ Another considerable advantage of this graft is its malleability through external finger manipulation for up to three weeks postoperatively. Histological evaluation was possible in 16 patients, 3, 6, and 12 months postoperatively and showed a mosaic-type alignment of graft cartilage with fibrous tissue connection among the fragments. ${ }^{7}$

Although this impressive results, and besides the cases described by Erol using both autologous cartilage grafts ${ }^{7}$ and cartilage homograft, ${ }^{8}$ there are not, as far as we know, any other works in literature reporting the efficacy of this technique.

On the other hand, Daniel and Calvert, ${ }^{9}$ using the same method, later found unexpectedly frequent absorption of the entire composite implant within only a few months. In that series, the authors performed 22 diced cartilage grafts wrapped in Surgicel ${ }^{\circledR}$, but this portion of the study was halted abruptly at four months. It became evident for the authors that all of the diced cartilage grafts wrapped in Surgicel ${ }^{\circledR}$ were beginning to absorb. Slight absorption was evident by six weeks on photographic reevaluation, and it became clinically evident to both the surgeon and the patient by three months. Five patients needed revision surgery. ${ }^{9}$ The authors then preformed 20 cases of diced cartilage grafts wrapped in fascia for primary and secondary aesthetic rhinoplasty and 8 cases of diced cartilage grafts
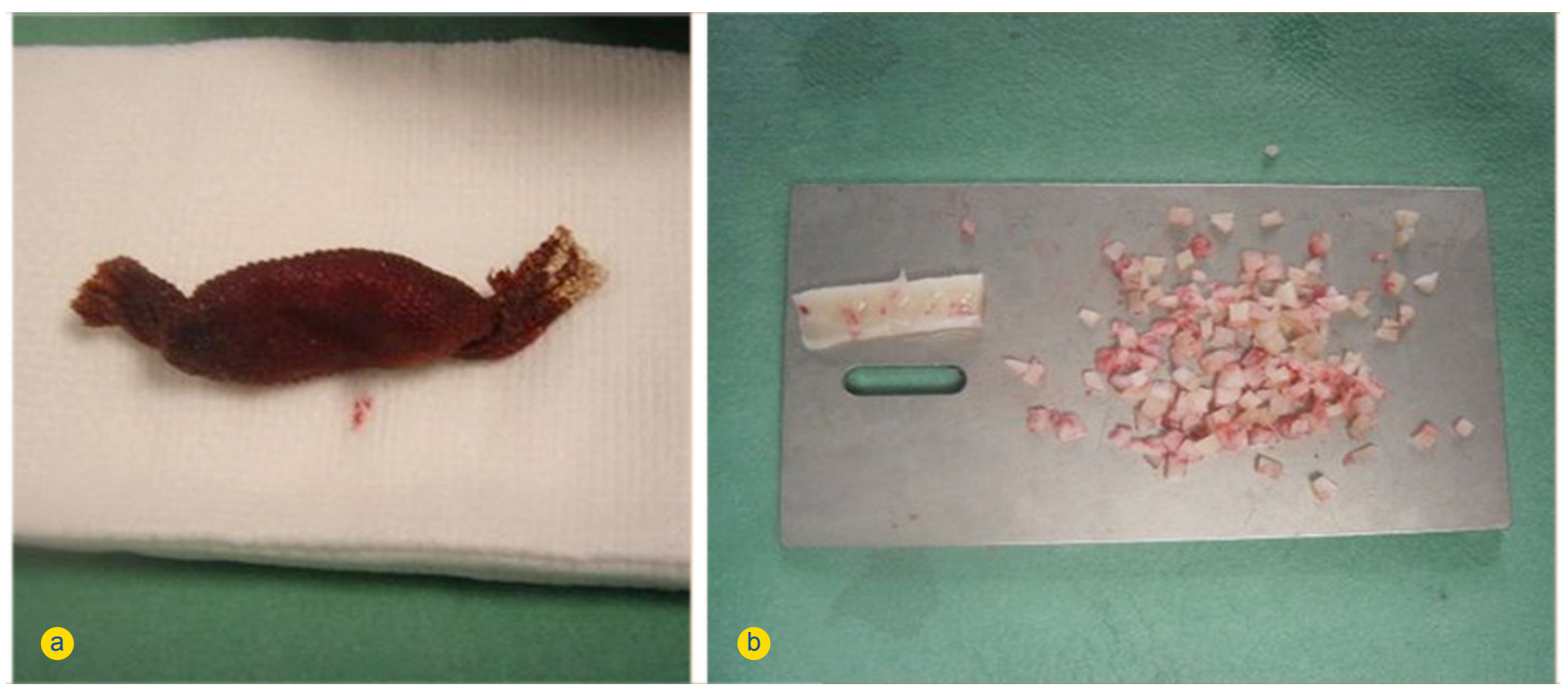

Figure 5 - Costal cartilage cuted in pieces of 0.5 to $1 \mathrm{~mm}(\mathrm{a})$ and wrapped in a layer of Surgicel ${ }^{\circledR}$ - Turkish delight (b). 
without a fascial covering placed throughout the nose. The follow-up showed maintenance of the grafts with no evidence of absorption at 12 and 14 months, respectively. The authors performed histological analysis of the biopsy of both specimens of diced cartilage grafts wrapped in Surgicel ${ }^{\circledR}$ and diced cartilage grafts wrapped in fascia. On the first specimens they observed evidence of fibrosis and lymphocytic infiltrates with small amounts of Surgice ${ }^{\circledR}$ visible on birefringent microscopy and remnants of cartilage metabolically inactive. On the specimen from diced cartilage grafts wrapped in fascia, they observed coalescence of the diced cartilage into a single cartilage mass, with viable cartilage cells and normal metabolic activity. ${ }^{9}$

In face with the significant discrepancy between Erol's ${ }^{7,8}$ and Daniel and Calvert's studies ${ }^{9}$ the following questions are raised: Is the Turkish Delight technique effective for augmentation and camouflage procedures in rhinoplasty? Why are the results of those studies so different? Daniel and Calvert ${ }^{9}$ defend that they used the graft for a different purpose of Erol's ${ }^{7}$ : they state that in the majority of Erol's case studies, the grafts were used for a 'camouflage' purpose to hide dorsal irregularities in primary rhinoplasty patients $^{7}$ and that in their series, the grafts were used for contour and to produce a distinct change in the nasal profile, augmenting the radix area and/or dorsum and to provide 'volume'. ${ }^{9}$ However, this cannot explain all the disparity found in both studies. Erol's ${ }^{7}$ also used Turkish Delight for secondary rhinoplasty in 350 patients with post rhinoplasty deformity, a series of cases more extensive than the one described by Daniel and Calvert. ${ }^{9}$ Those patients were submitted to secondary rhinoplasty to correct not only minor secondary deformities, but also more severe cases, including ski-jump deformity, saddle nose, and short nose, as well as in nasal reconstruction - although, he did not specify how many cases of severe secondary rhinoplasty were treated with Turkish Delight alone. ${ }^{7}$ Also in primary rhinoplasty patients, Erol $^{7}$ used Turkish Delight for augmentation of the tip without using a strut in the columella, and also describes this technique for low dorsum augmentation and contouring. As Daniel and Calvert, ${ }^{9}$ we were not able to find another reason to explain the disparity between both studies. . $^{7,9}$

On the other hand, in an experimental study, comparing the long-term stability of Turkish Delights, placed subperiosteal or subfascial in ten young rabbits, the authors observed absorption of the Turkish delight in both locations at 16 weeks. In fact, when the implant was placed subperiosteal, loss of thickness was determined to be 41.5 to 68.6 percent; and when the implant was placed in a subfascial plane, in the dorsal muscles of the rabbits, the implants was so highly resorbed that they were hardly noticeable. The histopathological analysis in those groups revealed only small groups of viable chondrocytes surrounded by the soft tissues associated to fibrotic changes. ${ }^{10}$ Although discouraging, this results cannot be fully taken, as the animal model and the location for placement of the Turkish Delight used, are not totally equivalent to human nasal reconstruction, representing only a reasonable approach.

We described a case of severe nasal deformity, successfully treated with a Turkish Delight. ${ }^{7}$ The patient presented us with a large cartilage defect, a thin skin nose, and a visible cartilage graft previously performed for the dorsum. It was decided that she was not a candidate for another carved or crushed cartilage graft. A secondary rhinoplasty, with Surgice $^{\circledR}$-wrapped diced cartilage graft technique ${ }^{7}$ was performed.

Autogenous material was preferred for numerous reasons including: normal consistency, flexibility, long-term survival, relative resistance to infection, and biocompatibility. ${ }^{9}$ The advantage of a diced-cartilage graft wrapped in Surgicel ${ }^{\circledR}$ over a fascia radix graft is the elimination of harvesting the fascia.

Although it was observed some reabsorption (about $30 \%$ of reabsorption in subjective evaluation by two different observers), more than the overcorrection performed and described by Erol, ${ }^{7}$ the technique was effective for nasal dorsum augmentation, providing contouring, maintain a smooth external contour, without significant visibility, or distortion. Both patient and surgeons were satisfied with the aesthetic result, as this was a challenging case, with few other options of treatment.

In conclusion, the technique of using Surgice ${ }^{\circledR}$-wrapped diced cartilage graft technique ${ }^{7}$ may be a technique for augmentation and camouflage of the nose, especially in cases of patients with thin skin nose, not prone to carved cartilage graft. The Surgice ${ }^{\circledR}$-wrapped diced cartilage graft offers flexibility in reconstructing difficult dorsal nasal deficiencies.

\section{ACKNOWLEDGMENT}

All images were published with the express full consent of the patient.

\section{CONFLICT OF INTERESTS}

There are no potential and real conflicts of interest with this article.

\section{FUNDING SOURCES}

There are no financial disclosures to be made with this article.

cartilage: a 43-year follow-up. Plast Reconstr Surg. 1992;89:131-5

4. Daniel RK. Rhinoplasty and rib grafts: evolving a flexible operative technique. Plast Reconstr Surg. 1994;94:597-609.

5. Peck GC Jr, Michelson L, Segal J, Peck GC Sr. An 18-year experience with the umbrella graft in rhinoplasty. Plast Reconstr Surg. 
1998:102:2158-65.

6. McKinney P, Loomis MG, Wiedrich TA. Reconstruction of the nasal cap with a thin septal graft. Plast Reconstr Surg. 1993;92:346-51.

7. Erol OO. The Turkish delight: a pliable graft for rhinoplasty. Plast Reconstr Surg. 2000;105:2229-41.

8. Velidedeoğlu H, Demir Z, Sahin U, Kurtay A, Erol OO. Block and Surgicelwrapped diced solvent-preserved costal cartilage homograft application for nasal augmentation. Plast Reconstr Surg. 2005:115:2081-93.

9. Daniel RK, Calvert JW. Diced cartilage grafts in rhinoplasty surgery. Plast Reconstr Surg. 2004;113: 2156-71.

10. Uysal A, Ozbek S, Ozcan M. Comparison of the biological activities of high-density porous polyethylene implants and oxidized regenerated cellulose-wrapped diced cartilage grafts. Plast Reconstr Surg. 2003;112:540-6. 


\section{Secondary Rhinoplasty Using the Technique of Turkish Delight: a Case Report and a Brief Review of the Literature}

Acta Med Port 2015:28:122-126

Publicado pela Acta Médica Portuguesa, a Revista Científica da Ordem dos Médicos

Av. Almirante Gago Coutinho, 151

1749-084 Lisboa, Portugal.

Tel: +351218428 215

E-mail: submissao@actamedicaportuguesa.com

www.actamedicaportuguesa.com

ISSN:0870-399X | e-ISSN: 1646-0758

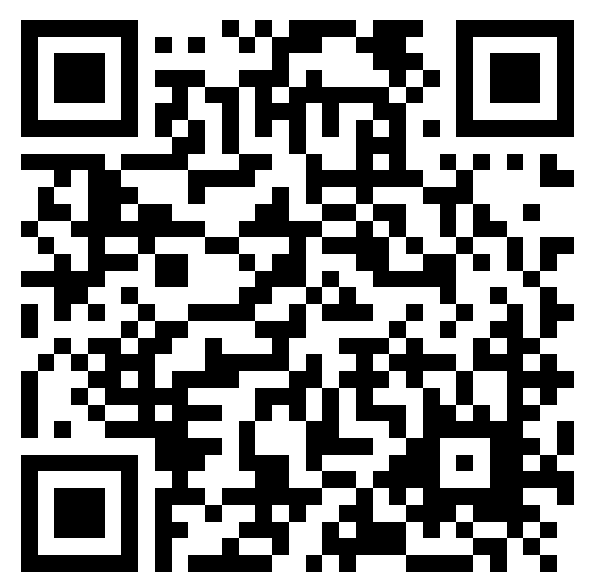

